\title{
LABORATORY STUDY ON SOIL STABILIZATION USING FLY ASH AND RICE HUSK ASH
}

\author{
Anil Kumar Singhai ${ }^{1}$, Sudhanshu Shekhar Singh ${ }^{2}$ \\ ${ }^{1}$ Professor, Civil Engineering Department, Government Engineering College Jabalpur, \\ $M P$, India \\ ${ }^{2}$ ME Student, Civil Engineering Department, Government Engineering College Jabalpur, MP, India
}

\begin{abstract}
The objective of this paper is to upgrade expansive soil as a construction material using rice husk ash (RHA) and fly ash, which are waste materials. Soil is a peculiar material. Some waste materials such Fly Ash, rice husk ash, pond ash may use to make the soil to be stable. Addition of such materials will increase the physical as well as chemical properties of the soil. Some expecting properties to be improved are CBR value, shear strength, liquidity index, plasticity index, unconfined compressive strength and bearing capacity etc. The objective of this study was to evaluate the effect of Fly Ash and Rice husk ash to improve the performance of black cotton soil. In this paper black cotton soil is treated with fly ash (5\%,10\%,15\%,20\%,25\%) and rice husk ash $(10 \%, 15 \%, 20 \%, 25 \%, 30 \%)$ and examine after 28 days of curing.
\end{abstract}

Keywords: Black cotton soil, Rice husk ash, Fly ash, and Stabilization

\section{INTRODUCTION}

Generally, lands with Black Cotton soils are fertile and very good for agriculture, horticulture, sericulture and aquaculture. Black cotton soils are expansive clays with potential for shrinking or swelling under changing moisture condition. The soils are formed under conditions of poor drainage from basic rocks or limestone under alternating wet or dry climatic conditions. In India, Most Indian Black Cotton Soils occupy an estimated area of 74 million hectare these soils are commonly observed in Maharashtra, western parts of Madhya Pradesh, Gujarat and some parts of Andhra Pradesh, Tamil Nadu, etc. Expansive soils pose problems to civil engineers in general and to geotechnical engineers in particular.

Clay is made up of tiny particles less than $0.002 \mathrm{~mm}$ in diameter. By comparison, for this reason, clay soils are considered to be fine textured. Clay soils any type of soil that contains a high percentage of clay particles. When discussing dirt, the term "clay" is basically a catch-all for a family of minerals that are heavy, Sticky, and dense. Clay soil can look different in different places, but it usually acts the same way.

Clay is normally understood to mean a clay soil whose grain is predominantly composed of clay minerals and which has plasticity and cohesion. The presence of water, which relatively unimportant in course grained soils plays a deceive role in engineering behavior of clay soil. On other hand, grain size distribution and grain shape influence the engineering behavior of granular soil and hardly affect the behavior of clay.

Hakari ${ }^{1}$, Udayashankar $\mathrm{D}^{2}$ has discussed in Indian geotechnical conference. (Dec-2010) has studied a use of fly ash for improves the property of black cotton soils of HubliDharwar region. The liquid limit decreases from $63 \%$ to $46 \%$, plastic limit from $28.9 \%$ to $23.1 \%$ and the plasticity index from $34.1 \%$ to $22.9 \%$; for the corresponding increase in the addition of DFA from $10 \%$ to $50 \%$ respectively. The shrinkage limit increases from $17.3 \%$ to $37 \%$ for increasing in the addition of DFA from $10 \%$ to $50 \%$ respectively the optimum moisture content decreases from $24.3 \%$ for $\mathrm{M}-10$ mix to $21.3 \%$ for M-50 mix. The CBR value Increases from $0.77 \%$ for M-10 mix to $2.64 \%$ for M-50 mix.

S. Bhuvaneshwari 1, R. G. Robinson 2, S. R. Gandhi ${ }^{3}$ (FAUP), TIFAC, DST, New Delhi (2005) has also discussed the stabilization of expansive Soils using fly ash extensive laboratory / field trials have been carried Out by out to check the improvements in the properties of expansive soil with fly ash in varying percentages.

The proper use of fly ash can reduce the cost of stabilization with pure cement or pure lime, as fly ash is a waste material. Lime during stabilization contributes to initial rapid improvement of the untrained soil strength due to cation exchange (Matsuo and Kamon, 1981), whereas fly contributes mainly to the long-term gain in strength and stiffness as a result of its time-dependent pozzolana reactivity (Kuganenenthira, 1990).

A small quantity of cement accelerates this process of pozzolana hardening. Quick lime decreases the soil plasticity more than the equivalent amount of hydrated lime (Mateos, 1964).Hydrated lime, although more expensive than quicklime, has the advantage of safety and convenience in handling. Normally, finely pulverized quick lime is used for soil stabilization of clay with reasonably high water content (Broms and Boman, 1977). 


\section{MATARIALS AND METHEODOLOGY}

\subsection{Black Cotton Soil}

It is collected from Patan Road District Jabalpur Madhya Pradesh from ground having coordinates21.2191 ${ }^{\circ} \mathrm{N}$, $81.3065^{\circ}$ E. soil sample is collected from location of Sukkha village, Power grid Office and near bypass of Jabalpur Patan road. Soil Sample is collected 1 meter below the original depth then collected into bag and send into the laboratory for examination.

\subsection{Rice Husk Ash}

IT is collected from virat vidut limited rice husk ash based Bio-Mass Power Plant at Bilaspur (C.G.),

\subsection{Fly Ash}

IT is collected from satpura thermal power station MPPGCL Sarni betul Madhya Pradesh.

Properties of black cotton soil define as per BIS standards and properties of black cotton soil, Rice husk ash and fly ash are tabulated on table

\subsection{Methodology}

The soil is collected from different location at Jabalpur and collects into bags and sends in laboratory for examination. First Index property of soil is determined after then fly ash and rice husk ash mix in different proportions in soil and put Into 28 days for curing. Total five combinations are formed and atterberg limit are evaluated in laboratory. The process of coal combustion results in fly ash.

The major constituents of most of the fly ashes are Silica ( $\mathrm{SiO} 2)$, aluminaAl2O3), ferric oxide (Fe2O3) and calcium oxide $(\mathrm{CaO})$. The other minor constituent of the fly ash are $\mathrm{MgO}, \mathrm{Na} 2 \mathrm{O}, \mathrm{K} 2 \mathrm{O}, \mathrm{SO} 3, \mathrm{MnO}, \mathrm{TiO} 2$ and unburnt carbon. There is wide range of variation in the principal constituents - Silica (25-60\%), Alumina (10-30\%) and ferric oxide (5$25 \%$ ). When the sum of these three principal constituents is $70 \%$ or more and reactive calcium oxides less than $10 \%$ technically the fly ash is considered as or class F fly ash.

It has a long history of use as an engineering material and has been successfully employed in geotechnical applications. The effect on parameters like free swell index (FSI), swell potential, swelling pressure, plasticity, compaction, strength and hydraulic conductivity of expansive soil was studied.

Table 1 Index Property of Black Cotton Soil

\begin{tabular}{|l|l|l|}
\hline Sr.No & Description of properties & Value \\
\hline 1. & $\begin{array}{l}\text { Particle size distribution } \\
\text { Sand (\%), Silt + Clay (\%) }\end{array}$ & $\begin{array}{l}8 \% \\
92 \%\end{array}$ \\
\hline 2. & Liquid limits & $40 \%-100 \%$. \\
\hline 3. & Plastic Limit & $25(\%)$ \\
\hline 4. & CBR & $1.5-2(\%)$ \\
\hline 5. & OMC (\%) & $26 \%$ \\
\hline 6. & MDD (Kn/m3) & 1.52 \\
\hline 7. & Free Swell index & $>50 \%$ \\
\hline
\end{tabular}

Table 2 Geotechnical properties of Rice husk ash

\begin{tabular}{|c|c|c|}
\hline Sr.No & Property & Value \\
\hline 1. & Specific Gravity & 1.95 \\
\hline 2. & Max. Dry Density & 8.5 \\
\hline 3. & $\begin{array}{l}\text { Optimum } \text { Moisture } \\
\text { Content }\end{array}$ & 31.8 \\
\hline 4. & $\begin{array}{l}\text { Angle of Internal } \\
\text { Friction }\end{array}$ & 38 \\
\hline 5. & Unsoaked CBR (\%) & 8.75 \\
\hline 6. & Soaked CBR (\%) & 8.15 \\
\hline
\end{tabular}

Table.3 Geotechnical properties Fly ash

\begin{tabular}{|l|l|l|l|}
\hline $\begin{array}{l}\text { Physical } \\
\text { Parameters }\end{array}$ & Value & $\begin{array}{l}\text { Physical } \\
\text { Parameter }\end{array}$ & Value \\
\hline $\begin{array}{l}\text { Silt and } \\
\text { Clay (\%) }\end{array}$ & 87 & $\begin{array}{l}\text { Coefficient of } \\
\text { uniformity Cu }\end{array}$ & 5.88 \\
\hline $\begin{array}{l}\text { Fine Sand } \\
(\%)\end{array}$ & 13 & $\begin{array}{l}\text { Coefficient of } \\
\text { Curvature Cv }\end{array}$ & 1.55 \\
\hline $\begin{array}{l}\text { Medium } \\
\text { Sand (\%) }\end{array}$ & 0 & $\begin{array}{l}\text { Specific } \\
\text { gravity }\end{array}$ & 2.55 \\
\hline $\begin{array}{l}\text { Coarse } \\
\text { Sand (\%) }\end{array}$ & 0 & $\begin{array}{l}\text { Plasticity } \\
\text { Index }\end{array}$ & $\begin{array}{l}\text { Non } \\
\text { Plastic }\end{array}$ \\
\hline
\end{tabular}

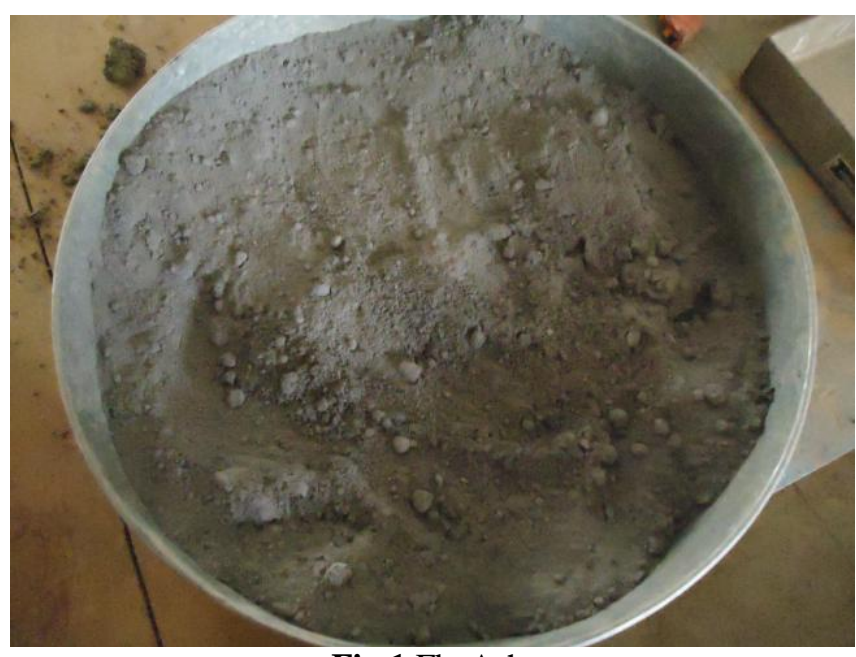

Fig 1 Fly Ash

\subsection{Results}

Table -4 Atterberg Test Results on Soil Sample

\begin{tabular}{|l|l|l|l|l|l|}
\hline $\begin{array}{l}\text { Soil } \\
\text { Sample }\end{array}$ & $\begin{array}{l}\text { Liquid } \\
\text { Limit }\end{array}$ & $\begin{array}{l}\text { Plastic } \\
\text { Limit }\end{array}$ & $\begin{array}{l}\text { Plasticity } \\
\text { Index }\end{array}$ & $\begin{array}{l}\text { Differe } \\
\text { ntial } \\
\text { Free } \\
\text { Swell }\end{array}$ & $\begin{array}{l}\text { Specific } \\
\text { Gravity }\end{array}$ \\
\hline $\begin{array}{l}\text { BC } \\
\text { SOIL }\end{array}$ & 53 & 30 & 27 & 35 & 2.61 \\
\hline $\begin{array}{l}\text { S1(5\%F } \\
\text { A+10\% } \\
\text { RHA) }\end{array}$ & 51 & 31 & 17 & 30 & 2.35 \\
\hline $\begin{array}{l}\text { S2(5\%F } \\
\text { A+10\% } \\
\text { RHA) }\end{array}$ & 54 & 42 & 12 & 25 & 2.40 \\
\hline $\begin{array}{l}\text { S3(5\%F } \\
\text { A+10\% } \\
\text { RHA) }\end{array}$ & 32 & 26 & 6 & 0 & 2.20 \\
\hline
\end{tabular}




\begin{tabular}{|c|c|c|c|c|c|}
\hline $\begin{array}{l}\mathrm{S} 4(5 \% \mathrm{~F} \\
\mathrm{A}+10 \% \\
\mathrm{RHA})\end{array}$ & 34 & 37 & 3 & $\begin{array}{l}\text { No } \\
\text { Swellin } \\
\mathrm{g}\end{array}$ & 2.01 \\
\hline $\begin{array}{l}\mathrm{S} 5(5 \% \mathrm{~F} \\
\mathrm{A}+10 \% \\
\mathrm{RHA})\end{array}$ & 0 & 0 & 0 & $\begin{array}{l}\text { No } \\
\text { Swellin } \\
\mathrm{g}\end{array}$ & 2.34 \\
\hline
\end{tabular}

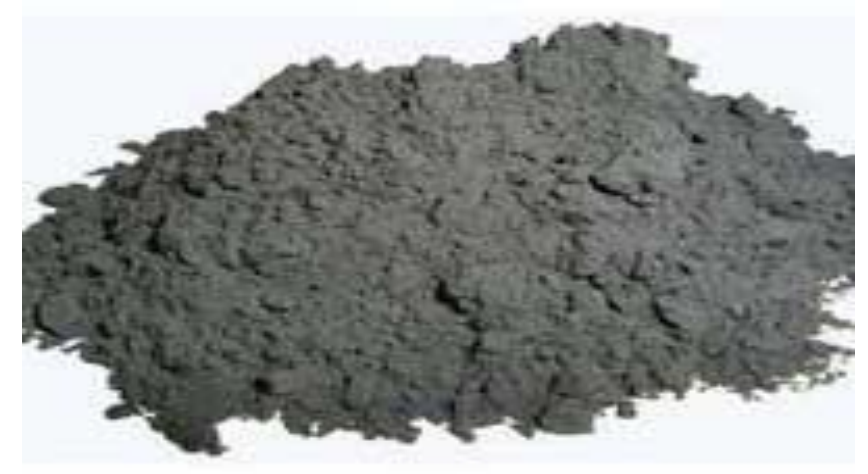

Fig 2 Rice Husk ASH

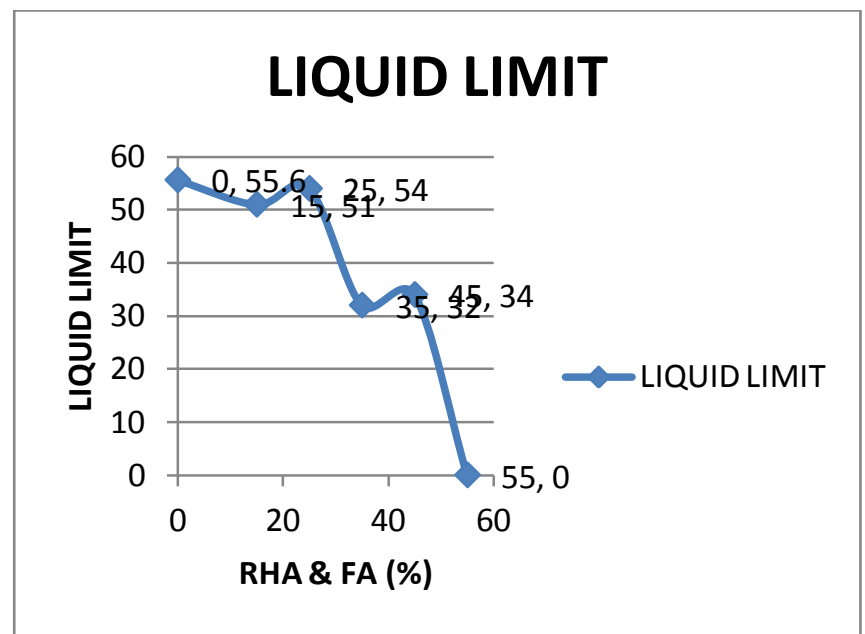

Fig-3 Liquid limit value for RHA, FA mix Soil sample

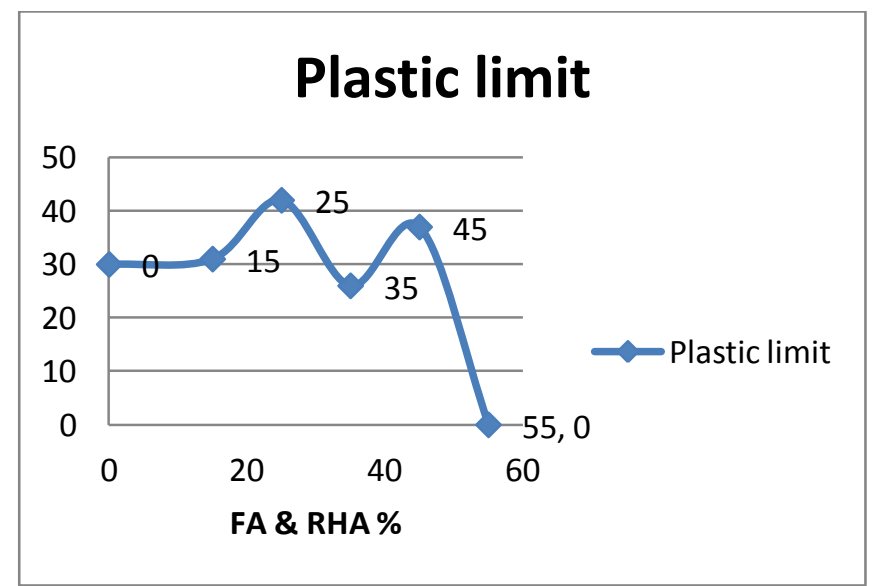

Fig-4 Plastic limit value for RHA, FA mix Soil sample

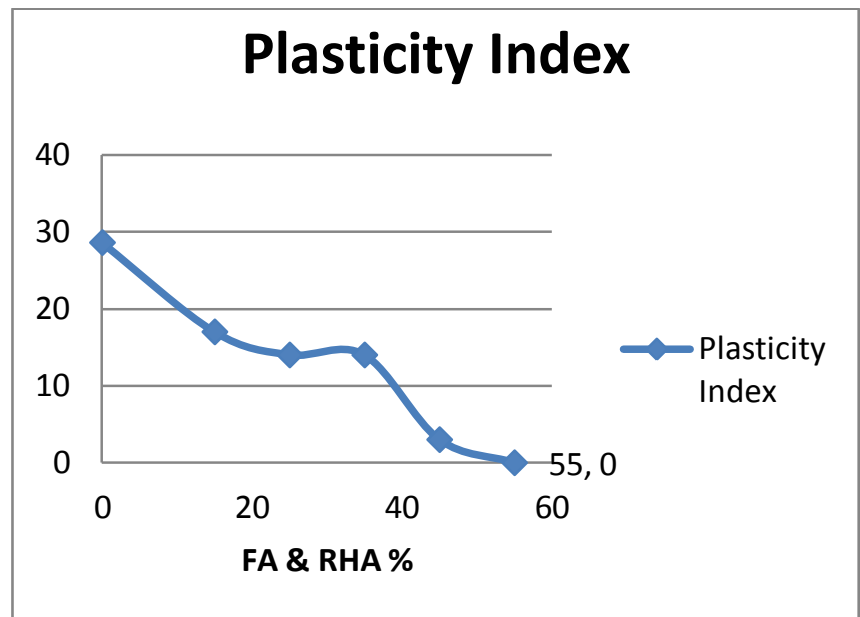

Fig-5 Liquid limit value for RHA, FA mix Soil sample

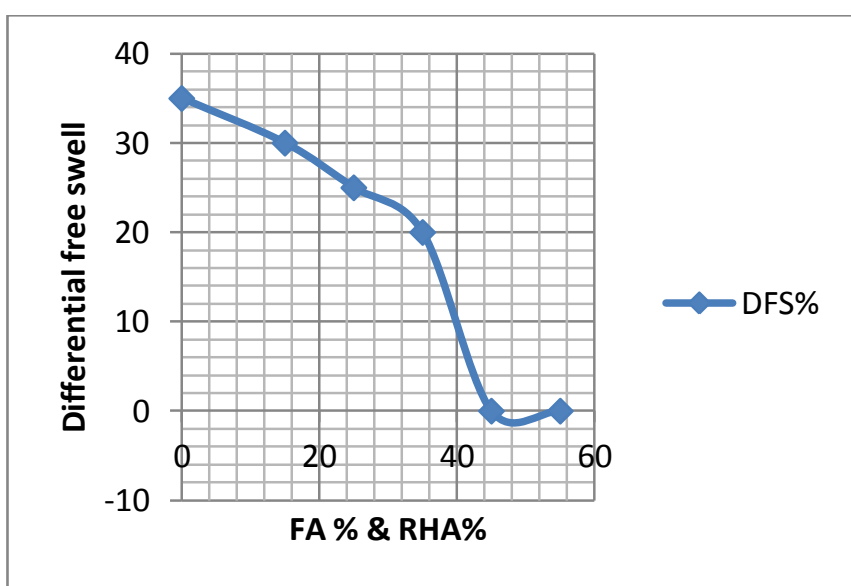

Fig- 6 Differential free swell value for RHA, FA mix Soil sample

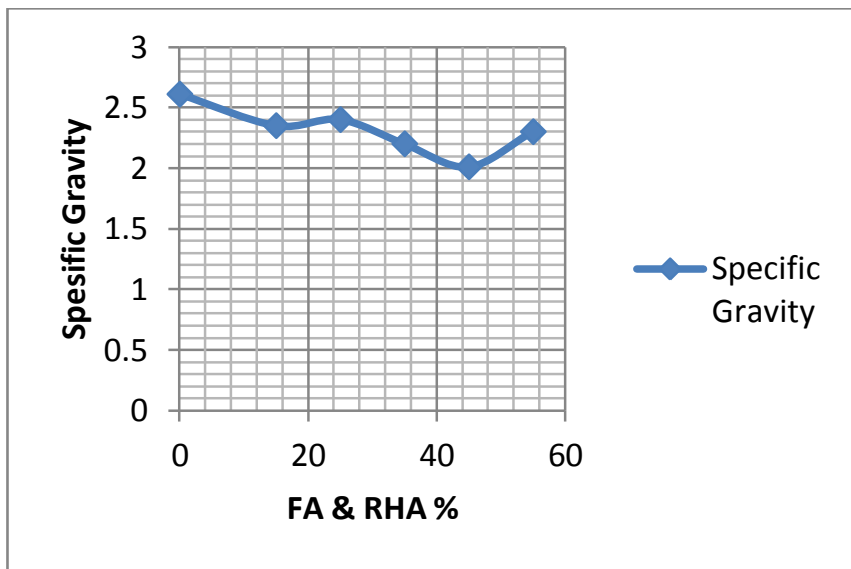

Fig-7 specific gravity for RHA, FA mix Soil sample

\section{CONCLUSIONS}

1. Liquid limit is reduced to $55 \%$ for $(20 \%$ FA and $25 \%$ RHA) mix soil sample.

2. Plasticity index is reduces to $86 \%$ for $(20 \%$ FA and $25 \%$ RHA) mix soil sample.

3. Differential free swell is reduces to $75 \%$ for $(15 \% \mathrm{FA}$ and $20 \%$ RHA) mix soil sample.

4. Specific gravity content is reduces. 


\section{REFERENCES}

[1]. Koteswara Rao, D., "Stabilization of Expansive Soil with Rice Husk Ash, Lime and gypsum", International Journal of Engineering Science and Technology (IJEST) ISSN: 0975-5462 Vol. 3, No. 11 November 2011.

[2]. Yadu, L.K., Tripathi, R.K., and Singh, D.V. (2011c). "Comparison of Fly Ash and Rice Husk Ash Stabilized Black Cotton Soil," International Journal of Earth Sciences and Engineering, Volume 04, No. 06 SPL, pp 42-45.

[3]. Muntohar, S., and Hantoro, G., (2000), "Influence Rice Husk Ash and Lime on Engineering Properties o a Clayey Sub-grade", Electronic Journal of Geotechnical Engineering, Vol. 5.

[4]. S. Bhuvaneshwari, R. G. Robinson and S. R. Gandhi, (2005), Stabilization of expansive soil using fly ash, Fly Ash Utilization Programme, (FAUP), TIAFC, DST, New Delhi

[5]. Erdal Cokca (2001) "Use Of Class C Fly Ashes for the Stabilization - of an Expansive Soil" Journal of Geotechnical and Geo environmental Engineering Vol. 127, July, pp. 568-5

[6]. Sudhira rath, "Lime Stabilization of Weak Sub-Grade for Construction of Rural Roads", International journal of earth sciences AND engineering Issn 0974-5904, vol. 05, no. 03 (01), June 2012, PP. 554-561

[7]. Osinubi K.J., (1999), "Evaluation of Admixture Stabilization of Nigeria Black Cotton Soil", Nigeria Soc. Engin. Tech. Trans., Vol. 34, No. 3, pp. 88-96.

[8]. R. Rama Rao. And P. V. Satyanarayana (2003) Use of RHA, Lime and Gypsum in strengthening sub-grade and sub base in low cost roads, National conference on modern cement and bituminous roads, Vizng PP 374-379. 